\title{
Miranda
}

Revue pluridisciplinaire du monde anglophone /

Multidisciplinary peer-reviewed journal on the English-

speaking world

$11 \mid 2015$

Expressions of Environment in Euroamerican Culture / Antique Bodies in Nineteenth Century British

Literature and Culture

\section{Remembering Peter Sculthorpe (1929-2014)}

\section{Christopher Connolly}

\section{(2) OpenEdition \\ 1 Journals}

Electronic version

URL: https://journals.openedition.org/miranda/7576

DOI: $10.4000 /$ miranda.7576

ISSN: 2108-6559

\section{Publisher}

Université Toulouse - Jean Jaurès

\section{Electronic reference}

Christopher Connolly, "Remembering Peter Sculthorpe (1929-2014)", Miranda [Online], 11 | 2015, Online since 21 July 2015, connection on 08 September 2022. URL: http://journals.openedition.org/miranda/ 7576 ; DOI: https://doi.org/10.4000/miranda.7576

This text was automatically generated on 8 September 2022

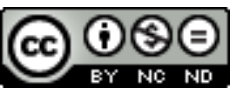

Creative Commons - Attribution-NonCommercial-NoDerivatives 4.0 International - CC BY-NC-ND 4.0 https://creativecommons.org/licenses/by-nc-nd/4.0/ 


\title{
Remembering Peter Sculthorpe (1929-2014)
}

\author{
Christopher Connolly
}

1 When Peter Sculthorpe died in Sydney last August the world lost a major creative figure. He was arguably the greatest composer Australia had produced. The event provoked an enormous public response and the press everywhere in the English speaking world gave ample space for the many fine tributes and obituaries that were written. For several weeks the Sydney Symphony Orchestra played his Memento Mori as an encore at each of its concerts to thunderous applause. His creative output totaled almost 400 works and he had a distinguished academic career for several decades as a member of Sydney University's music department from which he finally retired as Emeritus Professor. He trained a vast number of Australian composers who have come to prominence, many of whom still speak of his legacy with affection and gratitude. A number of them followed his lead in studying and drawing inspiration from the musical traditions of Japan and Indonesia rather than those of Europe. Perhaps this was partially due to a fortuitous boyhood encounter in Melbourne with the expatriate composer and pianist Percy Grainger (1882-1961) who had enjoyed close friendships with both Edvard Grieg and Frederick Delius. When told that the boy intended to become a composer, Grainger advised the precocious youngster to forget about Europe and cast his eyes toward the "gong orchestras" (sic) of the north!

2 Like the writer D.H. Lawrence, whose work he greatly admired, Peter Sculthorpe was inhabited by a vision to which he remained steadfast. It accompanied him through a life of peaks and valleys, those triumphs and vicissitudes which are the lot of any sincere artist who is prepared to take risks in order to break new ground. I mention Lawrence here because Sculthorpe used texts culled from the novel Kangaroo to great effect in his work The Fifth Continent for speaker and orchestra. Let us go back to its first performance in Hobart late in 1963. The newly-appointed lecturer in Music at Sydney University had returned to Australia two years previously from Wadham College, Oxford, where he had ruffled quite a few feathers by candidly stating that his aim was 
to write Australian music, a notion that few were prepared to take seriously at the time!

3 Sculthorpe had enlisted the aid of the Tasmanian Symphony Orchestra and the speaker was none other than the distinguished poet and critic, James McAuley who would publish his condensed epic poem, Captain Quiros the following year. The moving story of the famous Portuguese navigator whose dream of discovering and colonizing the South Land also fired Sculthorpe's creative imagination and to my mind it seems inconceivable that the older McAuley (also a musician) could have failed to be moved by the new Sculthorpe piece that he helped perform.

4 I quote here the antepenultimate stanza from Captain Quiros because I like to think that it was Peter Sculthorpe who finally fulfilled this prophetic wish with his superb music.

'Terra Australis, heartland of the South,

In the Great Lauds your myriad creatures raise

May there never be wanting the singer's mouth

To give words to that canticle of praise

which from all beings pours forth to the Spirit.

And from our broken toil may you inherit

A vision to transform your latter days.'

5 I first met Peter Sculthorpe in 2008. I had written to him the previous year to let him know how much I enjoyed listening to his music, mentioning the fact that whenever I did so it seemed that I was instantly spirited back to my native Australia. I also knew about the terrible bout of depression from which he had been suffering so I also sent him a seven-minute piano work entitled Sydney Harbour Nocturne which I dedicated to him as a gift. I soon received a very warm reply and we arranged to meet on my next visit to Sydney. I'll never forget the experience as he greeted me at his front door in the inner-city suburb of Woolhara. We went into his famous studio where there was a baby grand piano and a wall lined with books and we soon struck up a spirited conversation. I was in the presence of a man endowed with great natural charm. There wasn't the slightest trace of any affectation for he was warm-hearted and sincere. There was also a touching humility which you sensed had been acquired at a certain price and he made no attempt to parade his vast culture and erudition. I can't remember everything we touched on but we certainly compared musical life in France with musical life in Australia. He voiced his enthusiasm for Déodat de Séverac's piano music and he was excited when I told him the Toulouse Orchestre du Capitole was performing Delius's Walk to the Paradise Garden probably for the first time ever in France.

We discussed his use of plainchant in some of his works, notably in his Requiem, and he described the audience's ecstatic reaction to its first performance in Adelaide.

7 I visited him again during a subsequent visit to Australia, this time bringing him a bottle of wine, a Malepère, which is the wine made in my part of the Languedoc and we had another high-spirited conversation which never seemed to stop. He clearly loved talking to other composers.

Then, last July, I wrote to him asking him for some feedback about a work that I was recasting for string orchestra and was stunned when I received a message to the effect that he was just out of hospital and regretted not being able to help me for the moment. 
9 It was a great deal to have known him. As an Australian composer, I feel that I owe him much.

10

I will certainly cherish his memory.

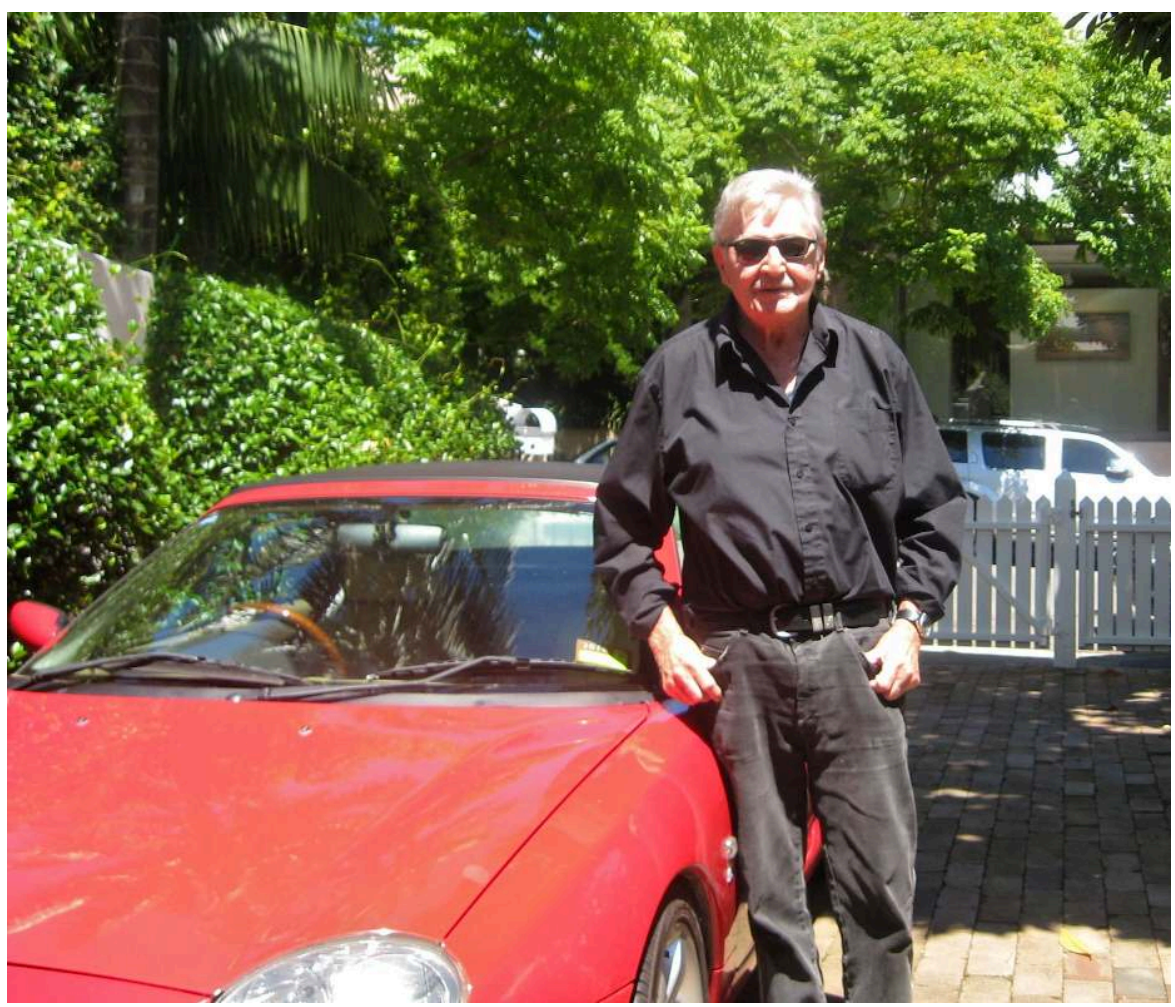

Peter Sculthorpe (by Chris Connolly)

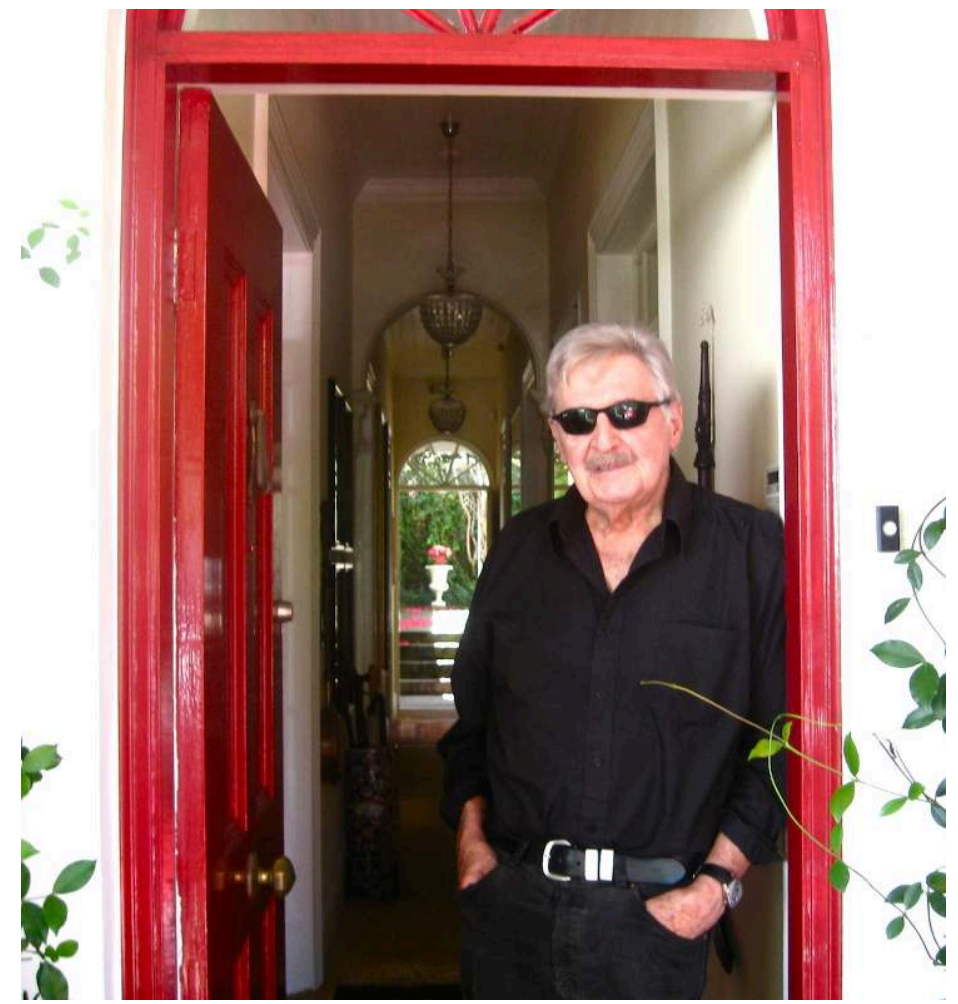

Peter Sculthorpe (by Chris Connolly). 
Sculthorpe, Peter. Sun Music. Sydney : ABC Books, 1999.

Skinner, Graeme. Peter Sculthorpe. The Making of an Australian Composer. Sydney :

University of New South Wales Press, 2007.

Interview with Peter Sculthorpe

https://www.youtube.com/watch ?v =ysascrWdeGo

A few links to works by Peter Sculthorpe

Earth Cry : https://www.youtube.com/watch ?v =g0MhMm09jvw

Kakadu : https://www.youtube.com/watch ?v =uhXoYfFX6ZA

Memento Mori : https://www.youtube.com/watch ?v =jxKBwtz27fA

Requiem : https://www.youtube.com/watch ?v =g0MhMm09jvw

INDEX

Subjects: Music

Keywords: Australia, composer, orchestra, piano

Mots-clés: Australie, compositeur, orchestre, piano

\section{AUTHORS}

\section{CHRISTOPHER CONNOLLY}

Chargé de cours

Université Toulouse-Jean Jaurès 